Vol. No. 1, Issue No. 1, December, 2017,55-68

Copyright () IIUM Press

eISSN 2600-8432

\title{
The Feasiblity of Al-Faruqi's Meta-Religion Principles: Sharing of Research Experience
}

\author{
Haslina Ibrahim*
}

\begin{abstract}
This paper shares part of the research experience in applying al-Faruqi's meta- religion principles for developing profile of religions in Malaysia. To capture the principles, two major categories have been recommended as the anchoring themes which are 'permanent' and 'dynamic'. The categories were tested by means of in-depth interviews with learned representatives of four major religions in Malaysia. This paper therefore focuses on sharing parts of the important processes involved in the research those are developing and testing the themes and the questions. The two processes have enlightened the researcher on the feasibility and the weaknesses of meta-religion principles as means for understanding religions.
\end{abstract}

Keywords: Meta-Religion, Inter-Religious Relations, Religious Studies, Comparative Religion.

\section{Introduction}

This paper is part of the research report on Ismā'îl Rājī alFaruqi's (d. 1986) meta-religion principles as alternatives to the existing methodologies in the study of religions. ${ }^{1}$ The study of religions has been propagated under several schools namely; Comparative Religion, History of Religion and Phenomenological Study of Religion. Comparative Religion has recently captures interest in Malaysia in some departments at public and private universities and it has been offered as

\footnotetext{
* Haslina bt. Ibrahim is Associate Professor, Department of Usuluddin \& Comparative Religion, Kulliyyah of Islamic Revealed Knowledge \& Human Sciences, International Islamic University Malaysia (IIUM) P.O.Box 10, 50728 Kuala Lumpur. Email: haslina@iium.edu.my

1 The research entitled Developing Profile Of Religions In Malaysia Using 'The Permanent And The Dynamic Aspects Of Religion" As A Category (1st December 2009 - 28th February 2012) received RM50,000.00 under the Fundamental Research Grant Scheme (FRGS) by the Ministry of Higher Education Malaysia (MOHE).
} 
part of the curriculum. ${ }^{2}$ In Islamic religious departments however, study of religions have been indirectly encountered from within theology through the works of Muslim theologians such as Ibn Hazm (d. 1064), al-Ghazālī (d. 1111) and Ibn Taymiyyah (d. 1328).

The widely accepted method since the nineteenth century up to the present time is the phenomenological method. It is claimed as scientific and descriptive method that avoid from doing judgment on religions under studied. Although al-Faruqiappreciated the method he has also shared his criticism on its pitfall in his book entitled Christian Ethics. ${ }^{3}$ He tried to build upon the phenomenological method by introducing the meta-religion principles. He adopted the principles in his study of Christianity as transpired in his Christian Ethics. It took him years before he started to advocate for the meta-religion as a world theology in 1986. At the same year he was assassinated leaving behind prospects for interpretation of his meta-religion. This paper therefore expects to share some of the research endeavor on applying the metareligion principles in comparing four major religions in Malaysia namely, Islam, Buddhism, Hinduism and Christianity. ${ }^{4}$

Learned representatives of religions have been identified and questions were derived from the meta-religion principles in order to examine the feasibility of the meta-religion principles as an approach in the study of religions.

\section{The Research Objectives}

The research is inspired by the initiative taken by al-Faruqi in

2 This discipline, however, is relatively a new discipline in Malaysia, though had been taught as a subject in some of the Islamic Department in the public universities in Malaysia that include the University of Malaya, National University of Malaysia and International Islamic University Malaysia.

${ }^{3}$ Ismā'̄̄l Rāj̄̄ al-Fārūq̄î, Christian Ethics: A Historical And Systemic Analysis Of Its Dominant Ideas, (Montreal: Mc Gill Univ. Press.1967).

4 The research would like to record its appreciation to the religious representatives who have been cooperative in the research interview. They were Dr. Ong See Yew from the Young Buddhist Association of Malaysia (YBAM), Dr. Wan Azhar Wan Ahmad from the Institut Kefahaman Islam Malaysia (IKIM), Dr. Hermen Shastri from the Christian Federation of Malaysia (CFM) and finally Mr. Radhakrishnan. Sanavagadamalai from the Malaysia Hindu Dharma Mahamandram (MHDM). 
molding what he regarded as a universal logic beyond religion in the study of religions. The reason for introducing such logic is due to his disagreement with the methods held in the study of religion at the western universities. Al-Faruqi claimed that it is important that one to ascribe to neutrality in the study of other religions to avoid biasness and prejudice. However, he persuaded that judgment should be involved. He introduced meta-religion as the principles of judgment and he claimed that they consist of universal logic that are not bias to any particular religious theology. The research tried to underscore al-Faruqi emphasis on the need of judgment in the study of religion. In order to examine the feasibility of meta-religion, the research has tried to simplify the questions to be posed to the learned representatives of religions in Malaysia.

\section{The Research Method}

The research is qualitative in nature and a learned representative of each religion has been identified to be interviewed. Before the interview was carried out the researcher had to simplify the metareligions principles into a set of themes and questions that are feasible for research inquiry. This was challenging as meta-religions are highly philosophical principles. In order to generate the themes and the questions, the researcher had to rely heavily on textual analysis of alFaruqiworks entitled "Christian Ethics and Towards A World Theology"5 in addition to other secondary materials on both works.

The themes and the questions were handed over in advance to the identified learned religious representatives before the interview. Meetings were held with them to explain the research, the themes and the questions. They have been given the least one month to understand and to study the themes and the questions. The interviews held were formal and audio-visual recorded in a studio. The rich information gained from the interviews has been comparatively and critically analyzed. Indeed it has been regarded as part of the research outputs and findings.

\section{Developing the Themes and the Questions}

5 Ismā'̄̄l Rājī al-Fārūq̄i, "Meta-Religion: Towards A Critical World Theology", American Journal of Islamic Social Sciences, Vol.3, No.1, 1986. 
The inspirational references for developing the themes and the questions were the works of two scholars; Ismā'îl Rājī al-Faruqi specifically on his ideas of the meta-religions and 'Irfān A.H. Fattāh on his demarcation between religion and religious thought. ${ }^{6}$ 'Irfān A.H. Fattāh propagates that religion in itself is characterized with a sense of finitude and dependence. Islamic religious thought on their hand is an open avenue for drawing analogies and references to convergences, between the different systems evolved in world religions. ${ }^{7}$ Inspired by the demarcation he made, the research postulated that every religion has finite characteristic and that religious thought on the other hand, is flexible and dynamic. The finiteness of religion is labeled as the permanent and the flexibility of the religious thought is labeled as the dynamic. Thus, a theoretical assumption of 'the permanent and the dynamic' was proposed as the main theme for the research inquiry and the meta-religion principles specified the issues under the main theme.

Al-Faruqi's meta religion principles tackle the basic questions man asked regardless of whether they are a believer or a non-believer. There are questions about life and existence, its constituents, its nature and purpose and its destiny. The research stipulates that the first principle (Being Is Of Two Realms: Ideal And Actual) seeks to explain reality/ies and the logical component/s of reality/ies. The second principle (Ideal Being Is Relevant To Actual Being) seeks to explain the relationship between and among the components. The third principle (Relevance Of The Ideal To The Actual Is A Command) justifies for the necessary relationship between and among the components. The forth principle (Actual Being Is As Such Good) describes the norms and values of the components. The fifth principle (Actual Being Is Malleable) justifies the norms and values of the components and finally the sixth principle (Perfection Of The Cosmos Is Only A Human Burden) justifies for the moral implications of a single component which is man.

Taking from the principles, the research concludes that there are five permanent issues in all religions. They are; Reality/ies and its constituents, the relationship between/among the constituents (be it there is relationship or not), the purpose of existence/life, the notion of good

6 'Irfān 'Abd al-Hamīd Fattāḥ, Al-Fikr al-Dīnī fì Muwājahat Tahaddiyāt al-ḥadāthah, (Kuala Lumpur: IIUM Press, 2002).

${ }^{7}$ Ibid. 
and bad and the destiny of life. The dynamic represent the rich and complex perspectives of the permanent. The dynamic is a result of philosophy, concept, methods, approaches and notion through which each issue under the permanent is deliberated. The dynamic therefore, lies within the religious thought.

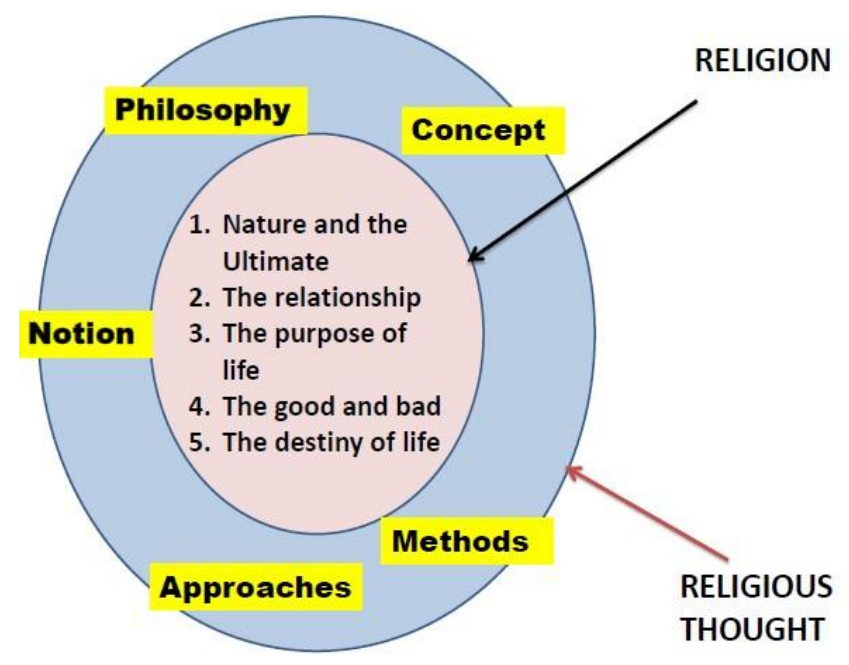

It is important to note that al-Faruqiintended to go beyond particular religious theology to advocate the universal logic of his metareligion principles. Interestingly, the universal logic helps one to understand differences in religions as part of reality; hence religious plurality. In this regard, meta-religion is not dogmatic as it requires intellection exercises. The researcher therefore tried to realize such an intellection exercise in the way that is feasible enough for the religious representative to respond.

Testing the Categories and the Research Findings: A Profile of Religions In Malaysia

The research questions have been divided into two set. The first set examined the respondents' opinion and understanding on the categories (the permanent and the dynamic). The second set is inquiries on the details of the categories from the respondents' religious perspectives.

As to measure their opinion on the categories, the respondents were asked if they are clear with the terminologies (permanent and 
dynamic) and their projected meaning as well as the demarcation between them. All the respondents agreed that they clearly understand with the categories.

When asked about the feasibility of the categories as the framework for understanding religion the respondents were generally positive. The Buddhist representative however highlighted that the term permanent coincides with the dualistic conception of permanent and impermanent in Buddhism.

As for Hinduism, the term permanent is likely to be understood as the fundamentals in Hinduism whereas the dynamic refers to the way of life in Hinduism. The Christian respondent thought that the categories would fit very well especially for the Judeo-Abrahamic traditions and those religions that have very strong regard for monotheistic perspective of God. In fact the Christian respondent agreed that the categories make it possible for discussion between Islam and Christianity in Malaysia. As for the Muslim representative he exerted that the categories must exist in every religion or otherwise religion is incomplete. Based on the responses it is concluded that the categories (permanent and dynamic) are well accepted and regarded feasible by the respondents. With exception to the Buddhist respondent who made an observation on the term 'permanent', the rest of respondents acknowledged that the categories did not conflict with the basic teachings in their religions.

Moving to the categories, the research has identified the five major themes under the permanent and proposed them as common themes in religion to the respondents. All of them agreed and accepted the themes as basic questions posed by their religions. Such submission has allowed the research to pursue to the more challenging part of the research. As expected, it is at this part that diverse responses were given depending on the methods, approaches, conceptions, and philosophies adopted by the respondents. Such dynamicity is summarized as follows:

Existence and its constituents, the relationship between/among the constituents (be it there is relationship or not), the purpose of existence/life, the notion of good and bad and the destiny of life.

\section{On The nature/s and its constituents}

The research found that Islam, Christianity, Hinduism, and Buddhism view that there exist the Ultimate and the cosmos and its components in life. It is only in Buddhism that the Ultimate is not 
recognized as the creator. The Ultimate (which is usually regarded as god in other religions) is called divine being, and there exist many of them who are living in the different level of heavens. The divine being, in fact is part of the cosmos. There then exist many realms of life which include the realm of the divine being, the realm of the ghost, the realm of man and others.

The Ultimate in Buddhism is in fact, is to transcend beyond the circle of life and death in order to achieve Nirvana. Thus the Ultimate is not viewed in terms of god or divine being that creates, sustains or protects the cosmos. Rather it is about man liberating himself from the cycle of life and death.

Adversely, the Ultimate in Islam and Christianity is the God who does not only creates but sustains. In Islam the Ultimate is the Single God who has nothing else in comparison to Him. Therefore God belongs to a realm which is unique to Him alone as the Creator, the Sustainer, the Provider and the Protector. Other than God, is the realm of the creation for everything is God creation. Thus there exist the dual realm which is the realm of God the Creator and the realm of creation.

In Christianity however, the Ultimate/God cannot be discussed in separation of the centrality of Jesus Christ and his word and his revelation. Speaking about god's creation, there exist dual realm, the realm of heaven and the realm of earth and God is not divorced from either. God belong to the heavenly realm but he is also in touch with the earthly realm and thus he exists in both realms. Jesus is the Ultimate that belong to the earthly realm and God the Father belong to the heavenly realm. The Holy Spirit makes it possible for the Ultimate/God to be present in both realms.

In Hinduism the Ultimate/God has many names for he can be revealed in many forms which also explain his many roles including creating, sustaining and many others. The Ultimate/God is also the liberator of man (from the cycle of birth). Man is God children and this the main reason to the divinely quality which lies in human soul. Hinduism did not make a clear demarcation between the realm of god as creator and his creation. As a matter of fact, Hinduism is more concern on presenting the religion as the way of life; the restoration of man to his divinely quality that may liberate him from the cycle of birth.

In conclusion, the Ultimate is generally perceived as god except for Buddhism who put more emphasis on the God's role. The basic role 
of the Ultimate as creator is prevalent in Islam, Christianity and Hinduism (but not in Buddhism). Nonetheless, only Islam differentiates God clearly from His creation. His unique role as the Creator is strongly emphasis in Islam thus there lies a strict demarcation between Him and His creation. Christianity and Hinduism however focused on integrating him with His creation. Such is not the emphasis in Christianity and Hinduism while it is not the case at all for Buddhism.

Judgement: Based on the responses, we may evaluate if it is reasonable for a religion to regard the role of Creating to God as secondary to the rest of His attributes or to regard it as insignificant issue in religion. Would it be convincing and substantial enough for the followers to take the explanation from religions about existence and life? As a matter of fact, religion is expected to provide a profound insight to the followers about God existence before anything else for God/the Ultimate is central issue in religion. Should the religion fail to do so, it will not be able to explain other forms of existence and life. In other words, if any religion fails to explain the existence of its God/Ultimate, it will not be able to make sense of other form of existence too. Any religion could not afford such a failure.

\section{The relationship between the Ultimate and other beings.}

In Buddhism, the relationship of divine being with other beings is not a matter of discussion at all. In fact it is the relationship with Buddha, being the founder of the religion himself is well deliberated. Buddha is the teacher, an enlightened one whose path followed by the Buddhist. Buddha teaches man about how to understand his own man, about nature and about suffering, about meditation and rituals that help man to liberate himself from the world. Buddha however is not god though he may be venerated by some Buddhist followers.

Islam on the other hand, makes it clear the relationship of man as servant to God, his Creator as well as his Master to whom he submit. To realize the submission, man is entrusted to be His khaliffah, to administer the world; a task man is made accountable to God. Other creations in the universe are signs of God's creation and they help man in realizing his submission to God.

In Christianity, It is within the nature of god to be constantly in relationship with all that He created especially human being. Indeed the relational aspect provides an avenue for man to experience the being of God. The doctrine of Trinity is human language explaining the 
relationship and therefore it does not exhaust under the term Trinity alone. God is spoken as father and it is relational, that signifies his character as provider as sustainer. God is spoken as Jesus the son and the redeemer, who stretch out his hand to man, and God is spoken as the Holy spirit, as God creative force, reaching out and renewing. The doctrine of Trinity seeks to vindicate the relational affairs of man and god rather than his creative power in creating.

As for Hinduism the relationship of human and non-human to God is a relationship of Him as the creator and the rest as creation. God is single but he comes in different forms that relate to the creation. One best way to explain god is the relationship of god with human soul, an entity which has divine quality and therefore is potentially divine. The only way to restore the divine quality is through purification of one soul which may be achieved through good deeds.

Judgment: Based on the responses the research found that the issue of relationship with god is the most complex discussion about religion despite being the permanent theme in every religion. Deliberation on the relationship is diverse as it depends much on the philosophy, conception or revelation adhered to by a particular religion. Even at the point when the ultimate is perceived as the creator, the extent to which his role as the creator is differently emphasized in different religion. As far as the interview is concern only Islam emphasized on the role of God as the Creator. Buddhism denied this role. Christianity makes a central focus on the Trinitarian relationship while Hinduism is more concern on the restoration of divine quality to the human soul.

It is reasonable to expect that every religion to explain about how man and other beings in the universe relate with god/ultimate. If the relationship is not well-explain, it posed question on how would the former implicates the latter. Thus any religious injunction would be futile and its legitimacy would be questionable.

\section{The purpose of life/existence}

In Buddhism the purpose of life and existence is not discussed under the purview of nature as creation. Rather it is about human ability to control his mind. Life is not about man serving god or serving Buddha, the teacher. Life is all about how mind is able to control its understanding about everything around him, about suffering, about meditation and thus helping the person to achieve liberation (Nirvana). As for Islam, the 
purpose of life is consistent with the purpose of creation that is submission to God for at the end everything will return to God. This mean that the world is transition and it is temporal to a permanent world, the divinely realm which is the eternal realm. In Christianity, the purpose of life is to live by the word of God as manifested in the life of Jesus and to imitate the ethical life of Jesus. This is to encounter the rebellious nature of man and their predisposition to sin. In Hinduism, the purpose of life is to purify one soul for it is the only way one restored his divinely quality and thus liberates himself from the cycle of life and birth

Judgment: Looking at the answers provided by the respondents, it is found that the first three themes led to the deliberation on the very basic question about existence, the cause for existence and the reason behind existence. Buddhism offers an idea devoid of theistic perspective about basic questions in life for is all about an individual quest for spiritual fulfillment for getting enlightenment. As for the three religions; Islam, Christianity and Hinduism, they relied upon God/the Ultimate to give meaning in their life.

\section{The notion of good and bad}

The theme seeks to deliberate on the 'way of life' commendable by religion for it justifies the values adhered by and the vices forbid by the religion. It is justifiable to think that the Ultimate is the provider or the basis for the notion of good and bad in religion. The research findings support has support for such justification.

Buddhism perceives one's ability to differentiate from good and bad as central means for achieving Nirvana. Achieving Nirvana necessitates one to purify his mind. As Buddha teaches man of good from bad values, an enlightened mind is the mind of a virtuous person and thus he may be arrived at a point of liberation. Liberation means either one culminates the state of enlightened (just like Buddha) or one is liberated from the cycle of reincarnation. Thus, to achieve Nirvana, the Ultimate, a Buddhist is expected to acquire virtues and to discard vices as taught by the Buddha himself.

Islam refers good and bad to God, the Creator, who provides guidance for making value judgment through His revelation. Man is guided by the revelation to lead his life. In addition he is also to exercise his rational with the help of revelation. Muslim's judgment of good and bad and his way of life made him accountable to God. The reason for 
such accountability is because he is granted reasoning ('aql) and capacity (ikhtiyār) to think and to act upon his thinking. The two (reasoning and capacity) is the preamble of him being accountable for his action. Thus, man is responsible to his Creator who created him and provided him with the qualities that make him responsible. Should he fulfill his responsibility he will be rewarded. Should it be otherwise, he will be punished. The law of God (sharī'ah) is implicated on him as long as he lives in this world. As he leaves from this world, God repay him for his action. Such is indeed the abode of man's submission in Islam and how man's submission to God guides him in his action, acquiring good values and discarding vices.

As for Christianity, the idea of good and bad corresponds to the doctrine of original sin that man is born sinner and sin is against the will of god. From the doctrine of sin there arise issues on values and vices in Christianity. To be ethical is to live as God willed it, as revealed in Jesus Christ and thus the Christian is to follow the example of Jesus who lives by the word of God. Such advocates the centrality of Jesus for he epitomized the virtuous life of a devout Christian. And his crucifixion demonstrated the highest values taught and adhered in Christianity which is love.

In Hinduism, good and bad fall under the law of karma. Virtuous life leads to good karma or otherwise. Teachings about good and bad are inspired by the sacred texts of Hinduism. God gives man knowledge to differentiate between the two. Purification of soul is made through the comprehension of good deeds under which one liberate himself from the cyclical life (karma samsara) and later to achieve mystical union with god. One who engrossed himself in a vicious life will get stuck in the karma samsara and will never be able to liberate his soul.

Judgment: The four religions commend for a virtuous life and condemn evil. Every religion has its own way and perspective in deliberating good and evil and relating them to the Ultimate. However, as far as the interviews are concerned, most of the respondents were discussing values and vices in relation to man. The research now look forward for an answer if such a way of life commended by the religion has anything to do with the religious perspective on the destiny of life.

\section{The destiny of life}

It is reasonable to think that the way of living commendable by 
religion should correspond to the destiny of life. Otherwise, it is hard to justify the claim made on values and vices that are allegedly religious but secular in orientation.

Buddhism takes Nirvana as the destiny of life. It is to liberate oneself from the cycle of reincarnation. A Buddhist who follows the commendable way of life as taught by Buddha will likely to achieve Nirvana, a no birth and no death kind of situation. Such would be the ultimate point in life, the highest point arrived at by Buddha, the teacher who found Buddhism.

Islam on the other hand delineates the idea of hereafter, where all creation including man, will go back to Allah The Almighty. Man's action will be judged in front of other creations where he will be rewarded or punished according to the deeds he accomplished in this world.

In Christianity the destiny of all creation lies in the hand of God. For those who accepted Jesus would be put in the heavenly realm, the Kingdom of God, which indeed is the end of life. The kingdom of god is a renewed place and creation.

As for Hinduism, the end of life is perceived in two ways, either mystical unity with god in this world or absorption into him in the next world.

Judgment: It is important that the destiny be linked with the purpose of existence of man and other beings or otherwise there will be problem of consistency of truth. A religion is questionable by human logic if the reason for existence is not clearly explain, as simple as whether existence is temporal or permanent. If it is temporal there would be an end for it. If it is permanent what guarantees it. If man is to serve god/the ultimate, what he could achieve in return. Is his existence serving his destiny? These are questions that help man to make sense of religious truths or otherwise religion fails to satisfy human logic. At this point, man is free either to pursue his conviction or to suppress it.

\section{Conclusion}

This paper is a research-based write up on the applicability of meta-religion principles in understanding religions in Malaysia. The greatest challenge for the research is to transform the meta-religion principle from its philosophical outlook into a more feasible scheme for intellection exercise. The other challenge was to convince on the 
reliability of the principle and the schemes formulated as alternative methods (particularly to the western methods) in the study of religions. The other important nature of the principle is that it encourages judgment in the study of religions. On the other hand, the western methods latter refrain from doing judgment on the view that it will resulted into non-objectivity and biasness. The research uphold the metareligion approach as it supports for al-Faruqiexertion that every religious followers should be encouraged to get involved with intellection process on issues pertaining to religious truth and this requires judgment. As a matter of fact, 'religious truth' is the core business of every religion. The research therefore concluded that intellection process can been made possible by means of the principles and the proposed categories have proven to be feasible in realizing the intended process.

\section{References:}

Aasi, Ghulam Haider, Muslim Understanding of Other Religions: An Analytical Study of Ibn Hazm Kitab al-Fasl fi al-Milal wa al-Nihal, (Ann Arbor Michigan: Umi Research Press,2004).

Asma, A. Understanding Multicultural Malaysia: Delights, Puzzles and Irritations,(Petaling Jaya: Pearson, 2003),

Bari, A. A. Constitution of Malaysia: Text and Commentary, (Petaling Jaya: Prentice Hall, 2008).

Bryne, P. Prolegomena to Religious Pluralism, (London: Macmillan Press, 1995),

Chiew, H. T. Chinese Belief and Practices in South East Asia, (Petaling Jaya: Pelanduk Publication, 1993).

Corfield, J. J. Religion in West Malaysia and Singapore, (University of Hull, Centre for Southeast Asian Studies, 1991).

Al-Faruqi, Ismā'̄̄l Rājī Christian Ethics: A Historical And Systemic Analysis Of Its Dominant Ideas, (Montreal: Mc Gill Univ. Press, 1967).

Al-Fārūqī, Ismā‘̄il Rājī̄, Islam and Other Faiths, (Leicester: The Islamic Foundation, 1998).

Al-Faruqi, Ismail Raji, "Meta -Religion: Towards A Critical World Theology", The American Journal of Islamic Social Sciences, Vol. 3, No. 1, Sept 1986.

F. Yousif, A. Religous Freedom, Minorities and Islam: An Inquiry into the Malaysian Experience, (Kuala Lumpur: Thinker's Library, 1998).

Fattah, I. A. Al-Fikr al-Dīn̄ fì Muwājahat Tahaddiyat al-Hadāthah, Kuala Lumpur: IIUM Press. 2002).

Hasan, K. \&. "Religions and Belief" In A. S. Abdul Hamid, The Encyclopedia of Malaysia, (Singapore: Archipelago Press, 2008),

James, G. A. Interpreting Religions: the Phenomenological Approaches of Pierre Daniel Chantepie de la Saisaye, W.Bede Kristensen and Gerardus ca der 
Leeuw, (Washington DC: The Catholic Universityof American Press, 1995).

Kamaruzzaman, Kamar Oniah, Early Muslim Scholarship In Religionswissenschaft, (Kuala Lumpur: International Islamic University Malaysia, 2003).

Mohd Sulaiman, M. M. Religions in Malaysia, (Petaling Jaya: n.pl., 2006).

Panikkar, R. Philosophical Pluralism and The Plurality of Religions. In T. Dean, Religious Pluralism and Truth, (New York: State University of New York Press, 1995).

Smart, N. The Phenomenon of Religion, (London: MacMilan, 1973)

Thoha, A. M. "The Western Conception of Objectivity and Scientific." Intellectual Discourse, 17(1), (2009): 83-92.

Waardenburg, Jean Jacques. Muslim Perceptions of Other Religions; A Historical Survey, (New York:Oxford Press, 1999).

Waardenburg, Jean Jacques. Muslim and Others, (New York: Walter de Gruyter, 2003). 